\title{
Listeria monocytogenes in Export-approved Beef from Mato Grosso, Brazil: Prevalence, Molecular Characterization and Resistance to Antibiotics and Disinfectants
}

\author{
Larrayane A.C. Teixeira ${ }^{1}$, Fernanda T. Carvalho ${ }^{1}$, Deyse C. Vallim ${ }^{2}$, Rodrigo C.L. Pereira ${ }^{2} \mathbb{}($, \\ Adelino Cunha Neto ${ }^{1}$, Bruno S. Vieira ${ }^{3, *}{ }^{10}$, Ricardo C.T. Carvalho ${ }^{1}$ and \\ Eduardo E.S. Figueiredo $1, *$ (i) \\ 1 College of Nutrition, Federal University of Mato Grosso, 78060-900 Cuiabá, MT, Brazil; \\ larrayane@hotmail.com (L.A.C.T.); fefetavares_carvalho@hotmail.com (F.T.C.); \\ adeneto40@gmail.com (A.C.N.); ricardo_carvalho88@hotmail.com (R.C.T.C.) \\ 2 Laboratory of Bacterial Zoonoses, Oswaldo Cruz Institute, Oswaldo Cruz Foundation, \\ 21040-360 Rio de Janeiro, RJ, Brazil; vallim@ioc.fiocruz.br (D.C.V.); rod.lisboa@hotmail.com (R.C.L.P.) \\ 3 College of Animal Science, Federal Institute of Education, Science and Technology of Mato Grosso, \\ 78580-000 Alta Floresta, MT, Brazil \\ * Correspondence: vieirabs@hotmail.com (B.S.V.); figueiredoeduardo@ufmt.br (E.E.S.F.); \\ Tel.: +55-66-3512-7000 (B.S.V.); +55-65-3615-8811 (E.E.S.F.)
}

Received: 23 August 2019; Accepted: 14 October 2019; Published: 20 December 2019

\begin{abstract}
The Brazilian state of Mato Grosso is the largest producer and exporter of beef in the country, but few studies of relevance have been conducted to evaluate the microbiological safety of its products. This study aimed to estimate the prevalence of Listeria monocytogenes (LM) in export-approved beef from Mato Grosso and to characterize the isolates in terms of molecular properties and antimicrobial resistance. From a total of 50 samples analyzed, Listeria sp. was isolated in 18 (36\% prevalence). Listeria monocytogenes was confirmed in 6 (12\% prevalence). Among the serotype groups assessed by multiplex PCR, serotype 4 (4b, $4 \mathrm{~d}$ or $4 \mathrm{e})$ was the most prevalent. Although antibiotic resistance was not an issue, two strains isolated from different plants showed high resistance to sodium hypochlorite. Overall, this scenario causes concern because it puts at risk not only the Brazilian customer, but also the population of countries that import beef from Mato Grosso.
\end{abstract}

Keywords: antimicrobial resistance; beef; food safety; Listeria monocytogenes; PFGE; sodium hypochlorite

\section{Introduction}

Listeria monocytogenes (LM) is the causative agent of listeriosis, a foodborne disease that affects mainly at-risk populations such as the elderly, pregnant woman, newborns and immunocompromised individuals [1]. Due to the high susceptibility of these population groups and the potential of LM to generate severe bacteremia and systemic infections, mortality associated with the invasive form of listeriosis is generally high, reaching $25-30 \%$ of the patients [2].

Animal-source food has been implicated in many of the clinical cases of listeriosis in humans. The presence of LM has already been described in milk, cheese, meat, fish and sausage [3-5]. A characteristic trait of LM that increases its odds to persist in food processing environments even after sequential cleaning and disinfection measures is the ability to produce biofilms, which protects the bacterium from the action of disinfectants. In this situation, not only the risk of food contamination increases, but the chances of resistant strains to arise are greater [6,7]. 
Based on that, description of LM resistance to disinfectants-which was previously considered a rare event-has been increasing in the literature [8]. The same situation is happening with LM resistance to antibiotics $[9,10]$. Whether this last finding is the consequence of extensive usage of antibiotics in human medicine, in veterinary medicine, or cross-resistance to authorized molecules used as growth promoters in animal production is still an open discussion [11,12]. In any case, this lack of clarity only reinforces the need for regular inspection of LM food sources and study of isolates' profile in order to establish proper measures to reduce the risk of food contamination and to improve the effectiveness of treatments by health services.

According to the Brazilian Institute of Geography and Statistics, the state of Mato Grosso holds the largest cattle herd and leads the beef-export activity in the country, accounting for $16.6 \%$ of the total volume of beef exported by Brazil in 2016 [13]. Despite the multiple international regulations followed by export-authorized plants, Brazilian internal regulations only require the control of LM in ready-to-eat products [14,15]. Not surprisingly, recent surveys in Brazil [16] demonstrated that the prevalence of LM in Brazilian packaged beef is very similar to that of $16 \%$ estimated for the global prevalence of LM in fresh beef [17]. This scenario may put at risk not only the Brazilian population, but also the consumers from other countries that import fresh beef from Brazil, a group currently represented by 74 countries including China, the Netherlands, Italy and Turkey.

The objectives of this study were to estimate the prevalence of Listeria monocytogenes in export-approved beef from Mato Grosso, Brazil, to identify the circulating serotypes and lineages, to compare the genotypic characteristics of isolates and to characterize their profile of resistance to antibiotics and disinfectants.

\section{Materials and Methods}

\subsection{General Procedures}

During a six-month evaluation period, 50 beef samples from 13 different export-authorized processing plants in the state of Mato Grosso, Brazil were obtained from the regular material used in the pathogen monitoring program of the official inspection service. Samples (flank steak, 1-2 kg each) were aseptically collected immediately after packaging, put into sterile plastic bags and kept on ice for approximately $12 \mathrm{~h}$ before laboratory processing.

\subsection{Listeria sp. Isolation and Species Confirmation}

To investigate the occurrence of LM in the collected material, all samples were subjected to traditional and widely recommended procedures of isolation and identification of the pathogen [18], using half Fraser and Fraser broths (Difco, France) as selective enrichment media. First, aliquots of $25 \mathrm{~g}$ of each sample were included in $225 \mathrm{~mL}$ of half Fraser broth and incubated at $37^{\circ} \mathrm{C}$ for $24 \mathrm{~h}$. After this period, $0.1 \mathrm{~mL}$ of this primary enrichment broth was transferred into tubes containing $10 \mathrm{~mL}$ of Fraser broth and incubated at $37^{\circ} \mathrm{C}$ for $24 \mathrm{~h}$. At the end of this protocol, tubes showing dark color were considered presumptively positive for Listeria sp. Confirmation was obtained after differential plating $\left(35^{\circ} \mathrm{C}\right.$ for $48 \mathrm{~h}$ ) on Modified Oxford Agar (Oxoid, Basingstoke, UK) and Listeria Agar (Biocen, Campinas, Brazil). Typical black colonies, small in the size and surrounded by a dark halo of aesculin hydrolysis, were considered as Listeria sp.

From each plate with characteristic growth, three colonies were isolated and further treated for Gram's staining and motility test. In addition, all the isolates were submitted to the biochemical proofs of catalase, hemolysis on 5\% Sheep Blood Agar (SBA), and xylose/rhamnose fermentation. To enhance the hemolytic activity of positive strains and resolve undetermined results, traditional CAMP test was performed for all isolates [19]. Gram positive colonies with the presence of umbrella-like motility, positive results for catalase, hemolysis (SBA or CAMP test) and rhamnose fermentation; negative results for xylose fermentation were considered as LM. 
Isolates were stocked in Brain Heart Infusion (BHI) broth $+0.5 \%$ Yeast Extract $+20 \%$ Glycerol at $-80{ }^{\circ} \mathrm{C}$ for LM confirmatory analysis using real-time PCR.

\subsection{Real-time PCR Confirmatory Assay}

Bacterial DNA was extracted from all isolates by thermal lysis and quantified by fluorometry using a Qubit device (Invitrogen, Singapore). Molecular confirmation of LM was performed in triplicate by real-time PCR, following the procedures originally described by Traunsek et al. [20] and modified by Moura et al. [21].

In short, one fragment of the $h l y A$ gene was amplified using primers and species-specific probe. Real-time PCR was optimized with $2 \times$ universal PCR master mix, $600 \mathrm{nM}$ of each primer, $200 \mathrm{nM}$ of the probe and $40 \mathrm{ng}$ of bacterial DNA. Amplification conditions were set to $10 \mathrm{~min}$ at $95{ }^{\circ} \mathrm{C}$, followed by 45 cycles of $15 \mathrm{~s}$ at $95^{\circ} \mathrm{C}$ and $1 \mathrm{~min}$ at $60^{\circ} \mathrm{C}$. Reactions were carried out in a 7500 Real Time PCR machine (Applied Biosystems, Waltham, MA, USA). The assay was controlled using DNA from LM (ATCC 7644), exogenous internal positive control reagents and DNase/RNase-free distilled water (Invitrogen, São Paulo, Brazil).

\subsection{Molecular Serotyping}

Multiplex PCR was carried out to assess both the serotype and lineage of the confirmed LM isolates. The protocol adopted here was originally proposed by Doumith et al. [22] and uses the amplification profile of the genes $l m o 0737$, Imo1118, ORF2819 and ORF2110 to separate LM into four groups: i) serotypes $1 / 2 \mathrm{a}$ or $3 a$, ii) serotypes $1 / 2$ c or $3 c$, iii) serotypes $1 / 2 b, 3 b$ or 7 , iv) serotypes $4 b$, $4 d$ or $4 \mathrm{e}$.

For that, bacterial DNA was extracted using a DNeasy Blood \& Tissue kit (Qiagen, Hilden, Germany), following the manufacturer's recommendations. The PCR assay was performed in a final volume of $50 \mu \mathrm{L}$ : $1 \times$ reaction buffer, $1.5 \mathrm{mM}$ of $\mathrm{MgCl}_{2}, 0.2 \mathrm{mM}$ of each $\mathrm{dNTP}, 10 \mathrm{pmol} / \mathrm{mL}$ of each primer and $0.5 \mathrm{U} / \mathrm{mL}$ of HotStar Taq polymerase (Qiagen, Hilden, Germany). The PCR reaction was set at $94{ }^{\circ} \mathrm{C}$ for $3 \mathrm{~min}$, followed by 35 cycles of $94{ }^{\circ} \mathrm{C}$ for $40 \mathrm{~s}, 53{ }^{\circ} \mathrm{C}$ for $1.15 \mathrm{~min}, 72{ }^{\circ} \mathrm{C}$ for $1.15 \mathrm{~min}$ and $72{ }^{\circ} \mathrm{C}$ for $7 \mathrm{~min}$. The gene prs was included in the reaction as positive control for Listeria sp. Listeria monocytogenes F6254 (serotype1/2c) was used as positive control for the genes $1 m 00737$ and $l m o 1118$; Listeria monocytogenes F4555 (serotype 4b), as positive control for the genes ORF2819 and ORF2110. The sequence of the primers and probe used in the molecular assays are sown in Table 1.

Table 1. Sequence and serotype specificity of primers and probes used in this study.

\begin{tabular}{|c|c|c|}
\hline Code & Sequence $\left(5^{\prime}-3^{\prime}\right)$ & Specificity \\
\hline hlyA & $\begin{array}{l}\text { F: AGAAGTNATTAGTTTTAAACAAATTTACTATAACG } \\
\text { R: AACTGCTCTTTAGTNACAGCTTTGC }\end{array}$ & Listeria monocytogenes \\
\hline hlyA Probe & FAM -TGAACCTACANGACCTTCC-MGB & Listeria monocytogenes \\
\hline prs & $\begin{array}{l}\text { F: GCTGAAGAGATTGCGAAAGAAG } \\
\text { R: CAAAGAAACCTTGGATTTGCGG }\end{array}$ & Listeria $s p$ \\
\hline $\operatorname{lmo0737}$ & $\begin{array}{l}\text { F: AGGGCTTCAAGGACTTACCC } \\
\text { R: ACGATTTCTGCTTGCCATTC }\end{array}$ & $\begin{array}{l}\text { Listeria monocytogenes } \\
\quad 1 / 2 \mathrm{a}, 1 / 2 \mathrm{c}, 3 \mathrm{a}, 3 \mathrm{c}\end{array}$ \\
\hline $\operatorname{lmo1118}$ & $\begin{array}{l}\text { F: AGGGGTCTTAAATCCTGGAA } \\
\text { R: CGGCTTGTTCGGCATACTTA }\end{array}$ & $\begin{array}{l}\text { Listeria monocytogenes } \\
\qquad 1 / 2 c, 3 c\end{array}$ \\
\hline ORF2819 & $\begin{array}{l}\text { F: AGCAAAATGCCAAAACTCGT } \\
\text { R: CATCACTAAAGCCTCCCATTG }\end{array}$ & $\begin{array}{l}\text { Listeria monocytogenes } \\
1 / 2 \mathrm{~b}, 3 \mathrm{~b}, 4 \mathrm{~b}, 4 \mathrm{~d}, 4 \mathrm{e}\end{array}$ \\
\hline ORF2110 & $\begin{array}{l}\text { F: AGTGGACAATTGATTGGTGAA } \\
\text { R: CATCCATCCCTTACTTTGGAC }\end{array}$ & $\begin{array}{l}\text { Listeria monocytogenes } \\
\qquad 4 \mathrm{~b}, 4 \mathrm{~d}, 4 \mathrm{e}\end{array}$ \\
\hline
\end{tabular}

Adapted from Doumith et al. [22].

The PCR products were separated in a $2 \%$ agarose gel, stained by ethidium bromide and visualized on a UV transiluminator coupled to a digital image analyzer (Kodak EDAS 290). 


\subsection{Genotypic Similarity}

Pulsed-field gel electrophoresis (PFGE) was used to separate LM isolates according to their genetic similarity. This assay followed the PulseNet/CDC protocol for LM and adopted ApaI as the primary restriction enzyme [23]. Salmonella Braenderup H9812 was digested by the XbaI enzyme and used as a molecular weight standard [24]. The amplified fragments were separated in a $1 \%$ agarose gel on a CHEF-DR III (Bio-Rad, Hercules, CA, USA) equipment, stained by ethidium bromide and visualized in a UV transiluminator coupled to a digital image analyzer (Kodak EDAS 290). Results were interpreted using the Gel-J software.

The PFGE profiles were considered indistinguishable when exhibiting $100 \%$ similarity. Therefore, a single band difference was sufficient to define two PFGE profiles as different. Taking these characteristics into consideration, genetic similarity between isolates was formally tested using the Dice similarity coefficient with $1.5 \%$ tolerance. Additionally, a dendrogram of the PFGE profiles was constructed based on the UPGMA hierarchical clustering method [25].

\subsection{Antibiotic Resistance}

The six LM isolates were tested for antibiotic resistance using the disk-diffusion technique, as described by supplements M02 and M100 of the Clinical and Laboratory Standards Institute [26,27]. A total of 17 antibiotics from 11 different classes were assessed (Table 2). For that, LM isolates were incubated at $35^{\circ} \mathrm{C}$ in $5 \mathrm{~mL}$ of $\mathrm{BHI}$ broth until tubes reached a turbidity equivalent to that of a McFarland standard of 0.5. Aliquots of these solutions were spread above Mueller-Hinton agar, antibiotic disks were dispensed on the agar surface and plates were incubated at $35{ }^{\circ} \mathrm{C}$ for $20 \mathrm{~h}$. As no specific criteria on zone diameter breakpoints for LM are available, results were interpreted according to Staphylococcus spp. standards. Strains of Escherichia coli (ATCC 25922), Staphylococcus aureus (ATCC 25923) and Pseudomonas aeruginosa (ATCC 27853) were used as internal controls to validate antibiotic disc performance.

Table 2. Antibiotics and zone diameter breakpoints used in the disk-diffusion assay.

\begin{tabular}{|c|c|c|c|c|c|c|}
\hline \multirow[t]{2}{*}{ Antibiotic } & \multirow[t]{2}{*}{ Code } & \multirow[t]{2}{*}{ Class } & \multirow{2}{*}{$\begin{array}{c}\text { Disk } \\
\text { Content }(\mu g)\end{array}$} & \multicolumn{3}{|c|}{$\begin{array}{l}\text { Zone Diameter Breakpoints } \\
(\mathrm{mm}) \text { for Each Phenotype }\end{array}$} \\
\hline & & & & $S$ & I & $\mathbf{R}$ \\
\hline Ciprofloxacin & CIP & Fluoroquinolone & 5 & $\geq 21$ & $16-20$ & $\leq 15$ \\
\hline Enrofloxacin & ENR & Fluoroquinolone & 5 & $\geq 18$ & $15-17$ & $\leq 14$ \\
\hline Sulfonamides & SSS & $\begin{array}{l}\text { Folate pathway } \\
\text { inhibitor }\end{array}$ & 300 & $\geq 17$ & $13-16$ & $\leq 12$ \\
\hline Trimethoprim & TMP & $\begin{array}{l}\text { Folate pathway } \\
\text { inhibitor }\end{array}$ & 5 & $\geq 16$ & $11-15$ & $\leq 10$ \\
\hline $\begin{array}{l}\text { Trimethoprim }+ \\
\text { sulfamethoxazole }\end{array}$ & SXT & $\begin{array}{l}\text { Folate pathway } \\
\text { inhibitor }\end{array}$ & 23.75 & $\geq 16$ & $11-15$ & $\leq 10$ \\
\hline Ampicillin & AMP & Penicillin & 10 & $\geq 29$ & - & $\leq 28$ \\
\hline Nitrofurantoin & NIT & Nitrofuran & 300 & $\geq 17$ & $15-16$ & $\leq 14$ \\
\hline Gentamicin & GEN & Aminoglycoside & 10 & $\geq 15$ & $13-14$ & $\leq 12$ \\
\hline Rifampin & RIF & Ansamycin & 5 & $\geq 20$ & $17-19$ & $\leq 16$ \\
\hline Chloramphenicol & CHL & Phenicol & 30 & $\geq 18$ & $13-17$ & $\leq 12$ \\
\hline Florfenicol & FLF & Phenicol & 30 & $\geq 18$ & $13-17$ & $\leq 12$ \\
\hline Erythromycin & ERY & Macrolide & 15 & $\geq 23$ & $14-22$ & $\leq 13$ \\
\hline Azithromycin & AZI & Macrolide & 15 & $\geq 18$ & $14-17$ & $\leq 13$ \\
\hline Imipenem & IPM & Carbapenem & 10 & $\geq 22$ & - & $\leq 21$ \\
\hline Tetracycline & TET & Tetracycline & 30 & $\geq 19$ & $15-18$ & $\leq 14$ \\
\hline Cefoxitin & FOX & Cephem & 30 & $\geq 22$ & - & $\leq 21$ \\
\hline Cefepime & FEP & Cephem & 30 & $\geq 24$ & $21-23$ & $\leq 20$ \\
\hline
\end{tabular}

$\mathrm{S}=$ susceptible; $\mathrm{I}=$ intermediate; $\mathrm{R}=$ resistant. 
For each antibiotic tested, isolates were classified into one of three possible phenotypes: susceptible, intermediate resistance or resistant. Strains that showed resistance to three or more antibiotic classes were considered multi-drug resistant. At all stages, isolates were tested in duplicate.

\subsection{Disinfectant Susceptibility}

The six LM isolates were used to assess the minimal inhibitory concentration (MIC) of five chemical disinfectants by the broth macrodilution technique, as described in the supplements M07 and M100 of the Clinical and Laboratory Standards Institute [27,28]. For that, stock solutions eight times more concentrated than the manufacturers' recommended concentration were prepared for each disinfectant in sterile BHI broth. Manufacturers recommended concentrations were $187.5 \mathrm{mg} / \mathrm{L}$ for peracetic acid, $5000 \mathrm{mg} / \mathrm{L}$ for benzalkonium chloride, 20,000 mg/L for chlorhexidine, $2400 \mathrm{mg} / \mathrm{L}$ for sodium hypochlorite and $2000 \mathrm{mg} / \mathrm{L}$ for quaternary ammonium. From each of the stock solutions, 19 serial two-fold dilutions were prepared. Solutions were then inoculated with suspensions of the isolates (McFarland standard of 0.5 ), reaching a final concentration of $5 \times 10^{5} \mathrm{CFU} / \mathrm{mL}$.

After an incubation period of $20 \mathrm{~h}$ at $35^{\circ} \mathrm{C}$, MIC for each disinfectant was considered as the lowest concentration with no bacterial growth (no turbidity). The lack of bacterial growth was confirmed by plating aliquots of these tubes on Mueller-Hinton agar $\left(35^{\circ} \mathrm{C}\right.$ for $\left.24 \mathrm{~h}\right)$. At all stages, isolates were tested in duplicate.

\section{Results}

From the total of 50 samples assessed in this study, 18 (36\%) generated typical Listeria sp. colonies on Modified Oxford Agar. From those, six were confirmed as LM by both morphological/biochemical and PCR assays, leading to a prevalence of $12 \%(6 / 50)$ of the pathogen. Listeria sp. isolates came from beef obtained in nine different processing plants, but LM was confirmed in only four of them (Figure 1).

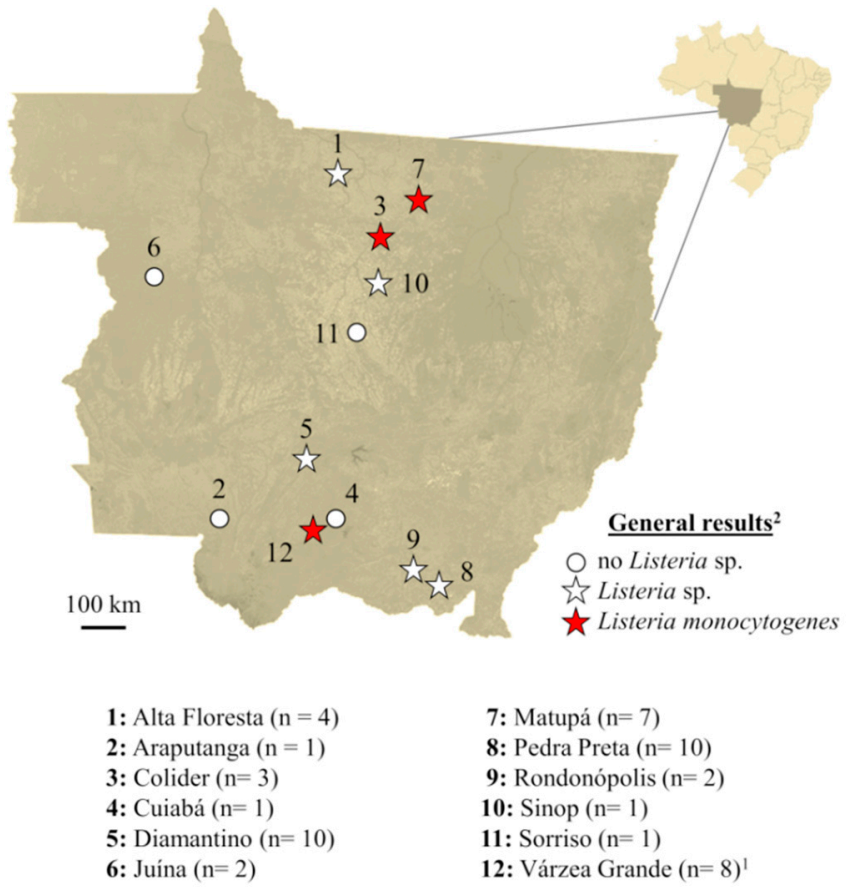

Figure 1. Geographic location (city) of processing plants, number of samples and general results for Listeria sp. and Listeria monocytogenes. ${ }^{1}$ In this city, two different processing plants were assessed ( $n=4$ /each) and both were positive for Listeria monocytogenes. ${ }^{2}$ Confirmation of Listeria monocytogenes were obtained by morphology/biochemistry and real-time PCR. 
Among the serotype groups evaluated by multiplex PCR, serotype 4 was the most prevalent (Figure 2). This serotype $(4 \mathrm{~b}, 4 \mathrm{~d}$ or $4 \mathrm{e})$ was isolated from samples obtained in the processing plants Várzea Grande 1 and 2, exclusively. Among them, only isolates 3 and 4 (originally from the processing plant Várzea Grande 2) demonstrated 100\% homology in the PFGE profile. Serotype group 1/2b, 3b or 7 was isolated from samples obtained in the processing plants Colíder and Matupá. Even though they had different origins, these two isolates (5 and 6) exhibited identical pulsotypes.

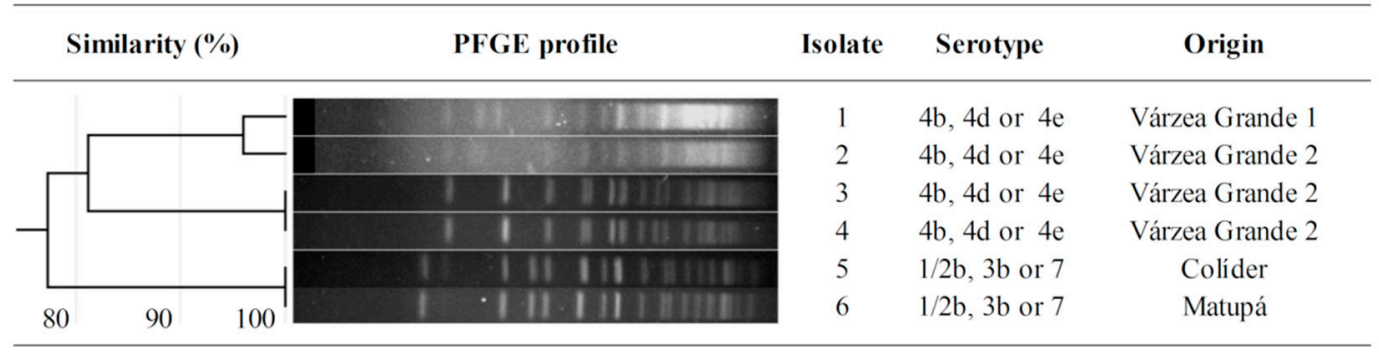

Figure 2. Genotypic similarity and serotyping of Listeria monocytogenes isolated from beef obtained in export-authorized processing plants of Mato Grosso, Brazil. Genotypic similarity was formally tested using the Dice similarity coefficient with $1.5 \%$ tolerance.

Using a broader approach to compare PFGE profiles within LM isolates, we observed that strains originated from processing plants Várzea Grande 1 and 2 had more than $81 \%$ similarity. However, by comparing the group of isolates from processing plants Várzea Grande 1 and 2 with that from processing plants Colíder and Matupá, no more than $76 \%$ similarity was observed.

In regard to the antimicrobial resistance assays, LM isolates were susceptible to most of the assessed antibiotics, although high rates of resistance were detected to sulfonamides, cefoxitin and cefepime (Table 3). Only the isolate 5 was considered susceptible to sulfonamides.

Table 3. Antibiotic resistance profile of Listeria monocytogenes isolated from beef obtained in export-authorized processing plants of Mato Grosso, Brazil.

\begin{tabular}{|c|c|c|c|c|c|c|c|}
\hline \multirow{2}{*}{ Antibiotic } & \multirow{2}{*}{ Code } & \multicolumn{6}{|c|}{ Resistance Profile $^{1}$} \\
\hline & & Isolate 1 & Isolate 2 & Isolate 3 & Isolate 4 & Isolate 5 & Isolate 6 \\
\hline Ciprofloxacin & CIP & $S$ & $S$ & $S$ & $S$ & $S$ & $S$ \\
\hline Enrofloxacin & ENR & $S$ & $S$ & $S$ & $S$ & $S$ & $S$ \\
\hline Sulfonamides & SSS & I & $\mathrm{I}$ & $\mathrm{R}$ & $\mathrm{R}$ & $S$ & $\mathrm{R}$ \\
\hline Trimethoprim & $\mathrm{TMP}$ & S & $S$ & $S$ & $S$ & $S$ & $S$ \\
\hline $\begin{array}{l}\text { Trimethoprim }+ \\
\text { sulfamethoxazole }\end{array}$ & SXT & S & $S$ & $S$ & $S$ & $S$ & $S$ \\
\hline Ampicillin & AMP & $S$ & $S$ & $S$ & $S$ & $S$ & $S$ \\
\hline Nitrofurantoin & NIT & S & $S$ & S & $\mathrm{S}$ & $S$ & $\mathrm{~S}$ \\
\hline Gentamicin & GEN & S & $S$ & S & $S$ & S & $S$ \\
\hline Rifampin & RIF & S & $S$ & S & $S$ & $\mathrm{~S}$ & $S$ \\
\hline Chloramphenicol & CHL & $S$ & $S$ & $S$ & $S$ & $S$ & $S$ \\
\hline Florfenicol & FLF & S & $\mathrm{S}$ & S & $\mathrm{S}$ & $\mathrm{S}$ & $\mathrm{S}$ \\
\hline Erythromycin & ERY & S & $S$ & $S$ & $S$ & $S$ & $S$ \\
\hline Azithromycin & AZI & S & $S$ & S & $S$ & S & $S$ \\
\hline Imipenem & IPM & S & $S$ & $S$ & $S$ & $S$ & $S$ \\
\hline Tetracycline & TET & $S$ & $S$ & $S$ & $S$ & $S$ & $S$ \\
\hline Cefoxitin & FOX & $\mathrm{R}$ & $\mathrm{R}$ & $\mathrm{R}$ & $\mathrm{R}$ & $\mathrm{R}$ & $\mathrm{R}$ \\
\hline Cefepime & FEP & $\mathrm{R}$ & $S$ & $\mathrm{R}$ & $\mathrm{R}$ & $\mathrm{R}$ & $\mathrm{R}$ \\
\hline
\end{tabular}

$\mathrm{S}=$ susceptible; $\mathrm{I}=$ intermediate; $\mathrm{R}=$ resistant. ${ }^{1}$ Determined by disk diffusion following the recommendations of the Clinical and Laboratory Standards Institute $[26,27]$. Isolate 1 was obtained from beef processed at plant Várzea Grande 1; isolates 2, 3 and 4 at plant Várzea Grande 2; isolate 5 at plant Colíder; isolate 6 at plant Matupá. 
A similar situation occurred for disinfectants: MICs of benzalkonium chloride, chlorhexidine, peracetic acid and quaternary ammonium were lower than their recommended concentration in all isolates (Table 4). Nevertheless, isolates 1 and 6 showed MIC of $7200 \mathrm{mg} / \mathrm{L}$ for sodium hypochlorite, a concentration three times higher than that recommended by the manufacturer.

Table 4. Minimal inhibitory concentration of chemical disinfectants for Listeria monocytogenes isolated from beef obtained in export-authorized processing plants of Mato Grosso, Brazil.

\begin{tabular}{|c|c|c|c|c|c|c|c|c|}
\hline \multirow{2}{*}{$\begin{array}{c}\text { Chemical } \\
\text { Disinfectant }^{2}\end{array}$} & \multirow{2}{*}{$\begin{array}{c}\text { Recommended } \\
\text { Concentration }(\mathrm{mg} / \mathrm{L})\end{array}$} & \multicolumn{7}{|c|}{ Minimal Inhibitory Concentration $(\mathrm{mg} / \mathrm{L})^{1}$} \\
\hline & & Isolate 1 & Isolate 2 & Isolate 3 & Isolate 4 & Isolate 5 & Isolate 6 & Average \\
\hline $\begin{array}{l}\text { Benzalkonium } \\
\text { chloride }\end{array}$ & 5000 & 0.6 & 9.8 & 4.9 & 4.9 & 4.9 & 1.2 & 4.4 \\
\hline Chlorhexidine & 20,000 & 0.2 & 0.2 & 0.4 & 0.2 & 1.6 & 0.4 & 0.5 \\
\hline Peracetic acid & 187.5 & 2.9 & 23.4 & 11.7 & 46.9 & 23.4 & 1.5 & 18.3 \\
\hline $\begin{array}{l}\text { Quaternary } \\
\text { ammonium }\end{array}$ & 2000 & 2.0 & 31.3 & 7.8 & 31.3 & 15.6 & 3.9 & 15.3 \\
\hline
\end{tabular}

${ }^{1}$ Determined by broth macrodilution, as described in the supplements M07 and M100 of the Clinical and Laboratory Standards Institute $[27,28] .{ }^{2}$ Benzalkonium chloride (CMT, Várzea Grande, Brazil), chlorhexidine (Rioquimica, São José do Rio Preto, Brazil), peracetic acid (Mustang Pluron, Brazil), quaternary ammonium (Mustang Pluron, Catanduva, Brazil) and sodium hypochlorite (Lima \& Pergher, Rio de Janeiro, Brazil) were tested in 20 concentrations, comprising stock solutions eight times more concentrated than the recommended dosage and 19 serial two-fold dilutions. Isolate 1 was obtained from beef processed at plant Várzea Grande 1; isolates 2, 3 and 4 at plant Várzea Grande 2; isolate 5 at plant Colíder; isolate 6 at plant Matupá.

\section{Discussion}

Our results indicated a 12\% prevalence of LM in export-approved beef from Mato Grosso, a number very similar to that of $11.4 \%$ obtained by Palma et al. [29] in beef from Brasília, capital of a neighbor state. Numbers from other countries indicate $23 \%$ prevalence of LM in beef from Chile [3], and $23.6 \%$ in beef from Italy [30]. This is in contrast to the prevalence of LM in beef from Ethiopia, Poland and Turkey, where lower values ranging from 2.5 to $7.2 \%$ have been reported [31-33].

It is important to note that despite the confirmed $12 \%$ prevalence of LM in beef from Mato Grosso, Listeria sp. reached a prevalence three times higher than that. Overall, nine of the 13 processing plants indirectly evaluated here were positive for Listeria sp. These findings cause concern as they indicate that these positive plants are also suitable for LM growth. According to Sauders and Wiedmann [34], the high DNA homology within the genus Listeria makes the ecology of species very similar, meaning they require analogous conditions to grow. This is a strong indication that more intensive measures of cleaning and disinfection must be adopted by the beef processing industry of Mato Grosso. This situation puts at risk not only the Brazilian customer, but also the population of the countries that import beef from those processors.

Most of the LM isolates belonged to serotype 4 (4b, $4 \mathrm{~d}$ or $4 \mathrm{e}$ ), but serotype group $1 / 2 \mathrm{~b}, 3 \mathrm{~b}$ and/or 7 were also detected. Unfortunately, the multiplex PCR protocol adopted here does not allow the complete differentiation of serotypes within these groups. Although serotyping provides biological context for the intra phylogenetic and phenotypic relationships between strains [35], the separation of LM into lineages allows a broader interpretation of the evolutionary aspects related to the origin of strains and provides better foundation to analyze the differences on their virulence and antimicrobial resistance. Genetic similarities between serotypes grant their classification into four different lineages [36]: lineage I is represented by serotypes $1 / 2 b, 3 b, 3 c$ and $4 b$; lineage II, by serotypes $1 / 2 \mathrm{a}, 1 / 2 \mathrm{c}$ and $3 \mathrm{a}$; lineages III and IV, by serotypes $4 \mathrm{a}, 4 \mathrm{~b}$ and $4 \mathrm{c}$.

From this perspective, LM isolated from plants Colíder and Matupá can be exclusively classified as lineage I, but LM isolated from plants Várzea Grande 1 and 2 could be part of lineages I, III or IV. Lineages I and II have been identified in the great majority of the clinical cases of listeriosis in humans [37,38], especially the serotype 1/2a (lineage II) which is also the most prevalent in food [39,40]. In a previous study by our research group, LM 1/2a was the predominant serotype (94.6\%) isolated 
from samples of chicken meat and chicken meat processing environment in Mato Grosso [41]. In the present study, no serotype 1/2a was identified in beef from Mato Grosso.

Despite the greater occurrence of LM lineage II in clinical cases of human listeriosis, lineage I is usually more virulent due to a premature stop codon frequently present in the virulence gene inlA of LM lineage II [42,43], which disrupts the translation of the gene and reduces bacteria potential for cellular invasiveness. In fact, by analyzing $38 \mathrm{LM}$ isolates from clinical (human) and non-clinical (food and food-related environment) samples obtained in Chile, Toledo et al. [44] found that the majority of the clinical isolates belonged to lineage I. Considering this, LM isolated here has a great potential of being harmful to humans, especially those from processing plants Colíder and Matupá, which are unambiguously assigned to lineage I.

The distance between processing plants proved to be an important element on the genetic similarity between isolates. Clone strains were detected in the processing plant Várzea Grande 2 (isolates 3 and 4) and also in the processing plants Colíder and Matupá (isolates 5 and 6). Even though these last processors were located in different cities, the distance between them was short (approximately $120 \mathrm{~km}$ ). In this condition, it is plausible to consider that animals raised in the same farm were slaughtered in both plants; or even that the personnel and trucks used to transport the animals were the same. These shared items, along with failures in the cleaning and disinfection procedures adopted by the industries, might explain the finding of clonal strains in samples from different plants. In contrast, less than $76 \%$ genetic similarity was detected when comparing the group of LM isolated from plants Várzea Grande 1 and 2 with that isolated from plants Colíder and Matupá. The distance between these sites ranged from 650 to $690 \mathrm{~km}$.

With respect to the antimicrobial susceptibility assays, results revealed low levels of antibiotic resistance. The exceptions were: i) cefoxitin and cefepime-not surprising as LM is naturally resistant to subclasses of cephems, especially cephalosporin [45]; ii) sulfonamides-this phenotype is of importance as the combination of trimethoprim and sulfonamides is the treatment of choice against listeriosis in penicillin-allergic patients [46]. However, resistance to the combination of trimethoprim and sulfamethoxazole was null in the present study.

Multi-drug resistant LM were previously isolated from beef in Italy [30] and Poland [32]. Resistance included drugs traditionally used to treat listeriosis, such as ampicillin, and others including vancomycin, tetracycline, erythromycin and oxacillin. Our results may indicate that the exposure of Mato Grosso's cattle to some of these molecules is low.

As well as that observed for antibiotics, resistance to disinfectants was sporadic in this study. All the isolates presented MICs below the recommended concentrations of benzalkonium chloride, chlorhexidine, peracetic acid and quaternary ammonium. This is in agreement with the results from Stoller et al. [47], who described no resistance to the typical usage concentration of benzalkonium chloride and peracetic acid in LM strains isolated in a Swiss meat-processing facility over a four-year period. However, two isolates (1 and 6) exhibited MIC of sodium hypochlorite three times higher than its recommended concentration. Resistance to sodium hypochlorite was already described in LM isolated from dairy facilities in Brazil [48]. The high availability and affordable price of this molecule make it one of the most used disinfectants by the food industry and production farms.

The presence of resistant strains in this study evinces not only the high usage of sodium hypochlorite in the production chain, but could also imply that the procedures of cleaning and disinfection are not being efficient enough to avoid the emergence and persistence of resistant strains in the processing environment. Listeria sp. are microorganisms of particular interest in this topic because their great ability to produce biofilms and protect themselves from the action of disinfectants $[16,49]$.

Differences in the choice of disinfectants, concentration of usage and efficacy of the cleaning and disinfection procedures between plants can also be the reason for the discrepant resistance profiles observed in isolates with $100 \%$ genetic homology. This situation occurred for isolates 5 and 6 , clones from different plants that showed, respectively, the lowest and the highest MIC for sodium hypochlorite. Same reasoning can be applied to antibiotic resistance: isolate 5 was susceptible to sulfonamides, while 
isolate 6 was not. These phenotypic differences between clone strains reinforce the rule of selective pressure as a determinant for the expression of antimicrobial resistance, even in microorganisms that share the same genotype.

\section{Conclusions}

The estimated prevalence of Listeria monocytogenes in export-approved beef from Mato Grosso is $12 \%$, but the prevalence of Listeria sp. reaches a value three times higher than that. Several serotypes and genotypic profiles circulate in the state; however, apparently clonal strains could be isolated in samples from different processing plants close to each other.

Antibiotic resistance was not an issue within the isolates, especially considering the molecules frequently used to treat listeriosis in humans. However, high level of resistance to the disinfectant sodium hypochlorite was detected in different strains. Overall, our results suggest that more intensive measures of cleaning and disinfection should be adopted by the beef industry of Mato Grosso.

Author Contributions: Conceptualization, L.A.C.T. and E.E.S.F.; methodology, L.A.C.T., D.C.V., A.C.N., R.C.T.C. and E.E.S.F.; formal analysis, L.A.C.T., D.C.V., B.S.V., R.C.T.C. and E.E.S.F.; investigation, L.A.C.T., F.T.C., R.C.L.P., A.C.N. and R.C.T.C.; resources, E.E.S.F. and D.C.V.; writing-original draft preparation, L.A.C.T., B.S.V. and E.E.S.F.; writing-review and editing, B.S.V., R.C.T.C. and E.E.S.F. All authors have read and agreed to the published version of the manuscript.

Funding: This research was funded by Capes Foundation, grant number 448262/2014-2 and CNPq Brazil, grant number 310462/2018-5.

Conflicts of Interest: The authors declare no conflict of interest. The funders had no role in the design of the study; in the collection, analyses, or interpretation of data; in the writing of the manuscript, or in the decision to publish the results.

\section{References}

1. Buchanan, R.L.; Gorris, L.G.M.; Hayman, M.M.; Jackson, T.C.; Whiting, R.C. A review of Listeria monocytogenes: An update on outbreaks, virulence, dose-response, ecology, and risk assessments. Food Control 2017, 75, 1-13. [CrossRef]

2. Hernandez-Milian, A.; Payeras-Cifre, A. What is new in listeriosis? Biomed Res. Int. 2014, $2014,1-7$. [CrossRef]

3. Saludes, M.; Troncoso, M.; Figueroa, G. Presence of Listeria monocytogenes in Chilean food matrices. Food Control 2015, 50, 331-335. [CrossRef]

4. $\quad$ Dhama, K.; Karthik, K.; Tiwari, R.; Shabbir, M.Z.; Barbuddhe, S.; Malik, S.V.S.; Singh, R.K. Listeriosis in animals, its public health significance (food-borne zoonosis) and advances in diagnosis and control: A comprehensive review. Vet. Q. 2015, 35, 211-235. [CrossRef] [PubMed]

5. Lakicevic, B.; Nastasijevic, I.; Raseta, M. Sources of Listeria monocytogenes contamination in retail establishments. Procedia Food Sci. 2015, 5, 160-163. [CrossRef]

6. Carpentier, B.; Cerf, O. Review-Persistence of Listeria monocytogenes in food industry equipment and premises. Int. J. Food Microbiol. 2011, 145, 1-8. [CrossRef] [PubMed]

7. Langsrud, S.; Sidhu, M.S.; Heir, E.; Holck, A.L. Bacterial disinfectant resistance-A challenge for the food industry. Int. Biodeterior. Biodegrad. 2003, 51, 283-290. [CrossRef]

8. Romanova, N.; Favrin, S.; Griffiths, M.W. Sensitivity of Listeria monocytogenes to sanitizers used in the meat processing industry. Appl. Environ. Microbiol. 2002, 68, 6405-6409. [CrossRef] [PubMed]

9. Cetinkaya, F.; Elal Mus, T.; Yibar, A.; Guclu, N.; Tavsanli, H.; Cibik, R. Prevalence, serotype identification by multiplex polymerase chain reaction and antimicrobial resistance patterns of Listeria monocytogenes isolated from retail foods: L. monocytogenes in raw and ready-to-eat foods. J. Food Saf. 2014, 34, 42-49. [CrossRef]

10. Kevenk, T.O.; Terzi Gulel, G. Prevalence, antimicrobial resistance and serotype distribution of Listeria monocytogenes isolated from raw milk and dairy products: Prevalence, antimicrobial resistance. J. Food Saf. 2016, 36, 11-18. [CrossRef]

11. Butaye, P.; Devriese, L.A.; Haesebrouck, F. Antimicrobial growth promoters used in animal feed: Effects of less well known antibiotics on Gram-positive bacteria. Clin. Microbiol. Rev. 2003, 16, 175-188. [CrossRef] [PubMed] 
12. Chattopadhyay, M.K. Use of antibiotics as feed additives: A burning question. Front. Microbiol. 2014, 5, 334. [CrossRef] [PubMed]

13. IBGE Brazilian Institute of Geography and Statistics. IBGE Indicators: Statistics of Animal Production; IBGE: Brasília, Brazil, 2017.

14. BRASIL Resolution ANVISA/RDC \#12. In Technical Regulation on Food Microbiological Standards; Diário Oficial da União: Brasília, Brazil, 2001.

15. BRASIL Normative Instruction MAPA \#9. In Procedures to Control Listeria monocytogenes Ready to Eat Animal-Source Products; Diário Oficial da União: Brasília, Brazil, 2009.

16. Camargo, A.C.; Woodward, J.J.; Call, D.R.; Nero, L.A. Listeria monocytogenes in food-processing facilities, food contamination, and human listeriosis: The Brazilian scenario. Foodborne Pathog. Dis. 2017, 14, 623-636. [CrossRef] [PubMed]

17. Jay, J. Prevalence of Listeria spp. in meat and poultry products. Food Control 1996, 7, 209-214. [CrossRef]

18. USDA United States Department of Agriculture. Microbiology Laboratory Guidebook. Isolation and Identification of Listeria monocytogenes from Red Meat, Poultry, Ready-to-Eat Siluriformes (Fish) and Egg Products, and Environmental Samples; USDA: Athens, GA, USA, 2017.

19. McKellar, R.C. Use of the CAMP test for identification of Listeria monocytogenes. Appl. Environ. Microbiol. 1994, 60, 4219-4225.

20. Traunsek, U.; Toplak, N.; Jeršek, B.; Lapanje, A.; Majstorović, T.; Kovač, M. Novel cost-efficient real-time PCR assays for detection and quantitation of Listeria monocytogenes. J. Microbiol. Methods 2011, 85, 40-46. [CrossRef]

21. Moura, G.F.; Tomborelli, P.M.; Carvalho, R.C.T.; Sigarini, C.O.; Carvalho, F.T.; Vieira, B.S.; Figueiredo, E.E.S. Listeria monocytogenes and other species as persistent contaminants in the processing of chicken meat. J. Appl. Poult. Res. 2019, 28, 470-478. [CrossRef]

22. Doumith, M.; Buchrieser, C.; Glaser, P.; Jacquet, C.; Martin, P. Differentiation of the major Listeria monocytogenes serovars by multiplex PCR. J. Clin. Microbiol. 2004, 42, 3819-3822. [CrossRef]

23. Graves, L.M.; Swaminathan, B. PulseNet standardized protocol for subtyping Listeria monocytogenes by macrorestriction and pulsed-field gel electrophoresisq. Int. J. Food Microbiol. 2001, 65, 55-62. [CrossRef]

24. Hunter, S.B.; Vauterin, P.; Lambert-Fair, M.A.; Van Duyne, M.S.; Kubota, K.; Graves, L.; Wrigley, D.; Barrett, T.; Ribot, E. Establishment of a universal size standard strain for use with the PulseNet standardized pulsed-field gel electrophoresis protocols: Converting the national databases to the new size standard. J. Clin. Microbiol. 2005, 43, 1045-1050. [CrossRef]

25. Sneath, P.; Sokal, R. Numerical Taxonomy. The Principles and Practice of Numerical Classification; W.H. Freeman and Company: San Francisco, CA, USA, 1973; ISBN 0-7167-0697-0.

26. CLSI Clinical and Laboratory Standards Institute. CLSI Supplement M02: Performance Standards for Antimicrobial Disk Susceptibility Tests, 12th ed.; CLSI: Wayne, NJ, USA, 2015.

27. CLSI Clinical and Laboratory Standards Institute. CLSI supplement M100: Performance Standards for Antimicrobial Susceptibility Testing, 27th ed.; CLSI: Wayne, NJ, USA, 2017.

28. CLSI Clinical and Laboratory Standards Institute. CLSI Supplement M07: Methods for Dilution Antimicrobial Susceptibility Tests for Bacteria that Grow Aerobically, 10th ed.; CLSI: Wayne, NJ, USA, 2015.

29. Palma, J.M.; Lisboa, R.C.; Rodrigues, D.P.; Santos, A.F.M.; Hofer, E.; Santana, A.P. Molecular characterization of Listeria monocytogenes from beef samples and cattle slaughterhouses located in the Federal District, Brazil. Pesqui. Veterinária Bras. 2016, 36, 957-964. [CrossRef]

30. Pesavento, G.; Ducci, B.; Nieri, D.; Comodo, N.; Lo Nostro, A. Prevalence and antibiotic susceptibility of Listeria spp. isolated from raw meat and retail foods. Food Control 2010, 21, 708-713. [CrossRef]

31. Gebretsadik, S.; Kassa, T.; Alemayehu, H.; Huruy, K.; Kebede, N. Isolation and characterization of Listeria monocytogenes and other Listeria species in foods of animal origin in Addis Ababa, Ethiopia. J. Infect. Public Health 2011, 4, 22-29. [CrossRef] [PubMed]

32. Wieczorek, K.; Dmowska, K.; Osek, J. Prevalence, characterization, and antimicrobial resistance of Listeria monocytogenes isolates from bovine hides and carcasses. Appl. Environ. Microbiol. 2012, 78, 2043-2045. [CrossRef] [PubMed]

33. Kalender, H. Prevalence of Listeria species in ground beef and chicken meat sold in eastern Turkey. Pak. Vet. J. 2012, 32, 456-458. 
34. Sauders, B.D.; Wiedmann, M. Ecology of Listeria species and L. monocytogenes in the natural environment. In Listeria, Listeriosis and Food Safety; CRC Press: Boca Raton, FL, USA, 2007; pp. 21-44.

35. Borucki, M.K.; Call, D.R. Listeria monocytogenes serotype identification by PCR. J. Clin. Microbiol. 2003, 41, 5537-5540. [CrossRef]

36. Orsi, R.H.; den Bakker, H.C.; Wiedmann, M. Listeria monocytogenes lineages: Genomics, evolution, ecology, and phenotypic characteristics. Int. J. Med. Microbiol. 2011, 301, 79-96. [CrossRef]

37. Montero, D.; Bodero, M.; Riveros, G.; Lapierre, L.; Gaggero, A.; Vidal, R.M.; Vidal, M. Molecular epidemiology and genetic diversity of Listeria monocytogenes isolates from a wide variety of ready-to-eat foods and their relationship to clinical strains from listeriosis outbreaks in Chile. Front. Microbiol. 2015, 6, 384. [CrossRef]

38. Bertrand, S.; Ceyssens, P.J.; Yde, M.; Dierick, K.; Boyen, F.; Vanderpas, J.; Vanhoof, R.; Mattheus, W. Diversity of Listeria monocytogenes strains of clinical and food chain origins in Belgium between 1985 and 2014. PLoS ONE 2016, 11, e0164283. [CrossRef]

39. Tappero, J.W. Reduction in the incidence of human listeriosis in the United States: Effectiveness of prevention efforts? JAMA 1995, 273, 1118-1122. [CrossRef]

40. Gilot, P.; Genicot, A.; Andre, P. Serotyping and esterase typing for analysis of Listeria monocytogenes populations recovered from foodstuffs and from human patients with listeriosis in Belgium. J. Clin. Microbiol. 1996, 34, 1007-1010. [PubMed]

41. Carvalho, F.T.; Vieira, B.S.; Vallim, D.C.; Carvalho, L.A.; Carvalho, R.C.T.; Pereira, R.C.L.; Figueiredo, E.E.S. Genetic similarity, antibiotic resistance and disinfectant susceptibility of Listeria monocytogenes isolated from chicken meat and chicken-meat processing environment in Mato Grosso, Brazil. LWT 2019, 109, 77-82. [CrossRef]

42. Jacquet, C.; Doumith, M.; Gordon, J.I.; Martin, P.M.V.; Cossart, P.; Lecuit, M. A molecular marker for evaluating the pathogenic potential of foodborne Listeria monocytogenes. J. Infect. Dis. 2004, 189, 2094-2100. [CrossRef] [PubMed]

43. Nightingale, K.K.; Ivy, R.A.; Ho, A.J.; Fortes, E.D.; Njaa, B.L.; Peters, R.M.; Wiedmann, M. InlA premature stop codons are common among Listeria monocytogenes isolates from foods and yield virulence-attenuated strains that confer protection against fully virulent strains. Appl. Environ. Microbiol. 2008, 74, 6570-6583. [CrossRef] [PubMed]

44. Toledo, V.; den Bakker, H.; Hormazábal, J.; González-Rocha, G.; Bello-Toledo, H.; Toro, M.; Moreno-Switt, A. Genomic diversity of Listeria monocytogenes isolated from clinical and non-clinical samples in Chile. Genes 2018, 9, 396. [CrossRef]

45. Krawczyk-Balska, A.; Markiewicz, Z. The intrinsic cephalosporin resistome of Listeria monocytogenes in the context of stress response, gene regulation, pathogenesis and therapeutics. J. Appl. Microbiol. 2016, 120, 251-265. [CrossRef]

46. Haubert, L.; Mendonça, M.; Lopes, G.V.; de Itapema Cardoso, M.R.; da Silva, W.P. Listeria monocytogenes isolates from food and food environment harbouring tetM and ermB resistance genes. Lett. Appl. Microbiol. 2016, 62, 23-29. [CrossRef]

47. Stoller, A.; Stevens, M.; Stephan, R.; Guldimann, C. Characteristics of Listeria monocytogenes strains persisting in a meat processing facility over a 4-year period. Pathogens 2019, 8, 32. [CrossRef]

48. Carandina, D. Evaluation of Biofilms Formed by Listeria Monocytogenes Isolated from Dairy Plants and Resistance to Sanitizing Agents. Master's Thesis, University of Sao Paulo, Pirassununga, São Paulo, Brazil, 2013.

49. Kocot, A.M.; Olszewska, M.A. Biofilm formation and microscopic analysis of biofilms formed by Listeria monocytogenes in a food processing context. Food Sci. Technol. 2017, 84, 47-57. [CrossRef]

(C) 2019 by the authors. Licensee MDPI, Basel, Switzerland. This article is an open access article distributed under the terms and conditions of the Creative Commons Attribution (CC BY) license (http://creativecommons.org/licenses/by/4.0/). 